\title{
Zuccagnia-type Propolis from Argentina: A potential functional ingredient in food to pathologies associated to metabolic syndrome and oxidative stress
}

\author{
Ana L. Salas (D, María Inés Mercado, Maria Eugenia Orqueda(D), Florencia M. Correa Uriburu(D, Maria Elena García(D), \\ María Jorgelina Pérez (D), María de los Angeles Alvarez(D), Graciela I. Ponessa (D), Luis Maldonado Maldonado(D, \\ Iris Catiana Zampini(i), and María Inés Isla (D)
}

\begin{abstract}
The effect of Argentine propolis extracts against enzymes related to metabolic syndrome and oxidative stress, as well as the botanical origin of raw propolis, were studied. Histological and chemical analyses of propolis samples revealed that the botanical origin is Zuccagnia punctata, an Argentine medicinal plant. The melissopalynological analysis showed both pollen grains of $Z$. punctata and the other plant species. This result indicates that the differences found in the botanical remains compared to the palynological studies may have been caused by the bees selecting resinous shrubs mainly of $Z$. punctata for the production of propolis and other plants with flowers for the production of honey.

The richness of propolis was remarkable in two flavonoid precursors $\left(2^{\prime}, 4^{\prime}\right.$-dihydroxy- $3^{\prime}$-methoxychalcone, $2^{\prime}, 4^{\prime}-$ dihydroxychalcone), the major chemical components of $Z$. punctata. The hydroalcoholic extracts of Argentine propolis and $Z$. punctata were able to inhibit enzymes associated with the metabolic syndrome, including $\alpha$-glucosidase, $\alpha$-amylase and lipase, with $\mathrm{IC}_{50}$ values between 7 to 14,37 to 48 , and 13 to $28 \mu \mathrm{g} / \mathrm{mL}$, respectively. Biological activity was mainly attributed to chalcones. Oxygen and nitrogen reactive species scavenging activity was determined by the assays of superoxide radical $\left(\mathrm{O}_{2}{ }^{-}\right)$, hydroxyl radical $\left(\mathrm{HO}^{\circ}\right)$, hydrogen peroxide $\left(\mathrm{H}_{2} \mathrm{O}_{2}\right)$, nitric oxide $\left(\mathrm{NO}^{*}\right)$, and cation radical $\left(\right.$ ABTS $^{*+}$ ). Results showed $\mathrm{SC}_{50}$ values between 115 to $278,12.50$ to $46 ; 39$ to $92 ; 50$ to 104.50 and 23 to $33.75 \mu \mathrm{g} / \mathrm{mL}$, respectively. This study suggests for the first time that propolis from Argentina is highly effective in inhibiting enzymes related to the metabolic syndrome and in free-radical scavenging that would justify its use as a dietary supplement or as a functional ingredient in special food.
\end{abstract}

Keywords: Argentine propolis, chalcones, free-radical scavenging activity, metabolic syndrome, Zuccagnia punctata

Practical Application: Propolis from Catamarca, Argentina, is traditionally used as medicine and food. Its botanical origin is Zuccagnia punctata, an endemic plant species popularly used as a medicine in Argentina. Propolis has the ability to regulate the activity of enzymes involved in the carbohydrate and lipid metabolism, and consequently in metabolic syndrome. Besides, its antioxidant capacity makes it a natural product that can be used as a dietary supplement or as a functional ingredient in special foods. It is important to highlight that in the Argentine Food Code, propolis was incorporated in 2008 as a dietary supplement and the present results give major added value to this product.

\section{INTRODUCTION}

Metabolic syndrome is a disorder associated to several pathologies: mainly diabetes, obesity, and cardiovascular condition. Slowing the digestion and breaking down starch may have beneficial effects to insulin resistance control. For this reason, both inhi-

JFDS-2020-0131 Submitted 1/26/2020, Accepted 5/12/2020. Authors Salas, Orqueda, Uriburu, Pérez, de los Ángeles Alvarez, Zampini, and Isla are from Instituto de Bioprospección y Fisiología Vegetal (INBIOFIV), CONICET-UNT, San Miguel de Tucumán, Tucumán, 4000 Argentina. Authors Salas, Uriburu, Zampini, and Isla are from Facultad de Ciencias Naturales, Universidad Nacional de Tucumán, San Miguel de Tucumán, Tucumán, 4000 Argentina. Authors Mercado, García, Ponessa, Zampini, and Isla are from Instituto de Morfología Vegetal, Área Botánica, Fundación Miguel Lillo, San Miguel de Tucumán, Tucumán, 4000 Argentina. Authors Uriburu and Maldonado are from Instituto Nacional de Tecnología Agropecuaria (INTA), Estación Experimental Agropecuaria Famaillá, Famaillá, Tucumán, 4132, Argentina. Direct inquiries to author Isla (E-mail: misla@tucbbs.com.ar).

*Zampini and Isla contributed equally. bition of enzymes related to carbohydrate metabolism, that is, $\alpha$-glucosidase and $\alpha$-amylase, and inhibition of lipolytic enzymes, such as lipase, are the most common therapeutic approaches to treat metabolic syndrome (Costamagna et al., 2016; Herrera, del Hierro, Fornari, Reglero, \& Martin, 2019; Spínola \& Castillo 2017). Thus, the discovery of hypoglycemic and hypolipemiant natural agents with a strong power and a weak side effect is highly desirable.

Propolis is a natural product obtained by Apis mellifera from resins collected from plants, widely used due to its medicinal properties (Coelho, Falcao, Vale, Almeida-Muradian, \& Vilas-Boas, 2017). In Argentina, propolis was included in the food code as an ingredient in sweets, honey, ethanolic extracts, and dietary supplements (Argentine Food Code, Chapter XVIII). Different propolis types have been reported in Argentina, depending on their botanical and geographical origin. Larrea divaricata and exotic Populus species are source of propolis from the Andean region (Isla et al., 2009; Kumazawa, Ahn, Fujimoto, \& Kato, 2010). Zuccagnia 
Table 1-Botanical studies of propolis samples collected from Catamarca.

\begin{tabular}{lcccclcc}
\hline Sample & Department & Locality & masl & Coordinates & \multicolumn{1}{c}{ Botanical species } & \multicolumn{1}{c}{ Family } \\
\hline C-I & Pomán & El Rincon & 1595 & $28^{\circ} 13^{\prime}$ S $66^{\circ} 08^{\prime} \mathrm{O}$ & Z. punctata Larrea sp. Sp1 & Fabaceae Zigophyllaceae Nonidentified & 100205 \\
C-II & Santa María & Santa María & 1885 & $26^{\circ} 41^{\prime} \mathrm{S} 66^{\circ} 02^{\prime} \mathrm{O}$ & Z. punctata & Fabaceae & 100 \\
C-III & Santa María & Santa María & 1885 & $26^{\circ} 41^{\prime} \mathrm{S} 66^{\circ} 02^{\prime} \mathrm{O}$ & Sp1 Z. punctata & Nonidentified Fabaceae & 100100 \\
\hline
\end{tabular}

* Percentage of samples with at least a fragment of a species.

masl, meters above sea level.

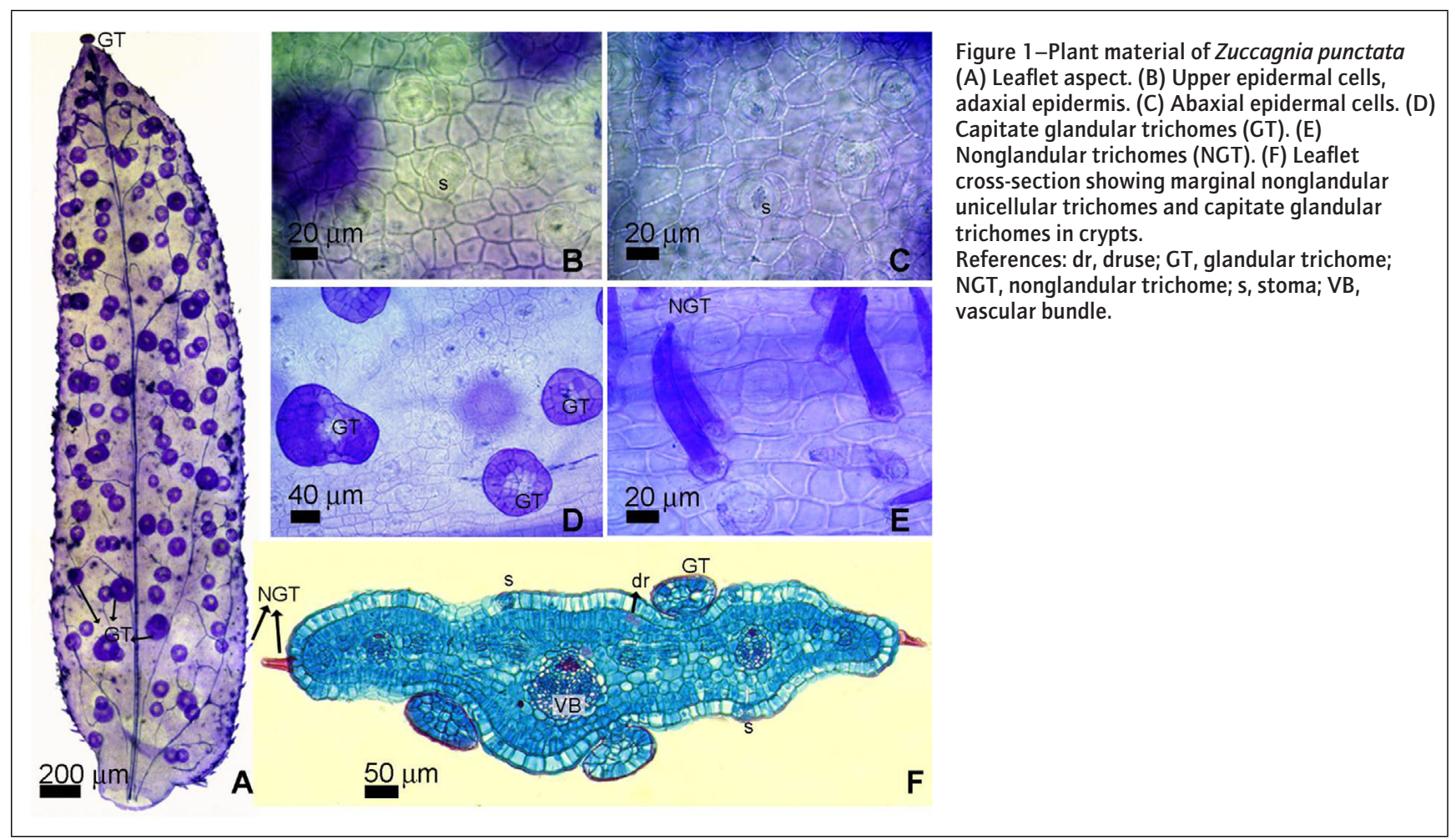

punctata has been assigned as the main botanical constituent of the propolis from semiarid region of Tucumán, which has been characterized by the presence of chalcones $\left(2^{\prime}, 4^{\prime}\right.$-dihydroxy- $3^{\prime}$ methoxychalcone, $2^{\prime}, 4^{\prime}$-dihydroxychalcone) as chemical markers (Salas, Alberto, Zampini, Cuello, et al., 2016; Salas, Mercado, Zampini, Ponessa, \& Isla, 2016). Both the bioactive chemical components and the functional properties, such as antifungal, antibacterial, antioxidant, anti-inflammatory, and antimutagenic, were previously reported in some Argentinean propolis types (Agüero et al., 2010, 2011, 2014; Isla, Paredes Guzman, Nieva Moreno, Koo, \& Park, 2005; Isla et al., 2009, 2012; Nieva Moreno, Isla, Cudmani, Vattuone, \& Sampietro, 1999; Nieva Moreno, Isla, Vattuone \& Sampietro, 2000; Nieva Moreno, Zampini, Ordoñez, Vattuone, \& Isla, 2005; Salas et al., 2014, 2016; Salas, Zampini, Maldonado \& Isla, 2018; Solórzano et al., 2012, 2017; Vera et al., 2011).

In this study, propolis samples were collected from Monte of Sierras and Bolsones, Catamarca, Argentina. This ecoregion shows a wide variety of characteristic native plant species such as jarillas, retama, mata sebo, montenegro, brea, pichana, and others (Morello, Matteucci, Rodriguez, \& Silva, 2012).

The aim of this article was to analyze the effect of propolis from Catamarca, Argentina, on enzymes linked to carbohydrate and lipid metabolism, as well as on oxidative stress and its botanical origin.

\section{MATERIALS AND METHODS}

\subsection{Propolis and plant species samples}

Propolis samples were collected from apiaries of National Apiculture Program INTA-PROAPI during four successive years between 2015 and 2018 from beehives located in El Rincón (C-I; $28^{\circ} 13^{\prime}$ S $66^{\circ} 08^{\prime} \mathrm{O}$ ) and Santa María (C-II, C-III; 26 41' S 66 $02^{\circ}$ $\mathrm{O})$, Catamarca, Argentina (Monte of Sierras and Bolsones ecoregion). The samples were collected following the usual method of scraping during the annual cleaning of the beehive. Grids were collected and frozen, and propolis were recovered, and stored at $-80{ }^{\circ} \mathrm{C}$ for further use.

Aerial parts of Zuccagnia puntacta Cav.; Larrea cuneifolia Cav., and L. divaricata Cav. were collected at the site where the beehives were located. All the plants were identified by Soledad Cuello $\mathrm{PhD}$ (INBIOFIV-CONICET). Samples were dried in a forced air oven at $40^{\circ} \mathrm{C}$.

\subsection{Preparation of propolis and native plant extracts}

Samples of raw propolis, $Z$. punctata, L. divaricata, and L. cuneifolia $(20 \mathrm{~g})$ were extracted with $250 \mathrm{~mL}$ of ethanol:water $80: 20 \mathrm{v} / \mathrm{v}$ assisted by ultrasound for $30 \mathrm{~min}$. Propolis extracts (PE) were taken to dry under reduced pressure, lyophilized, and stored at $-20{ }^{\circ} \mathrm{C}$ in the dark until analysis. 


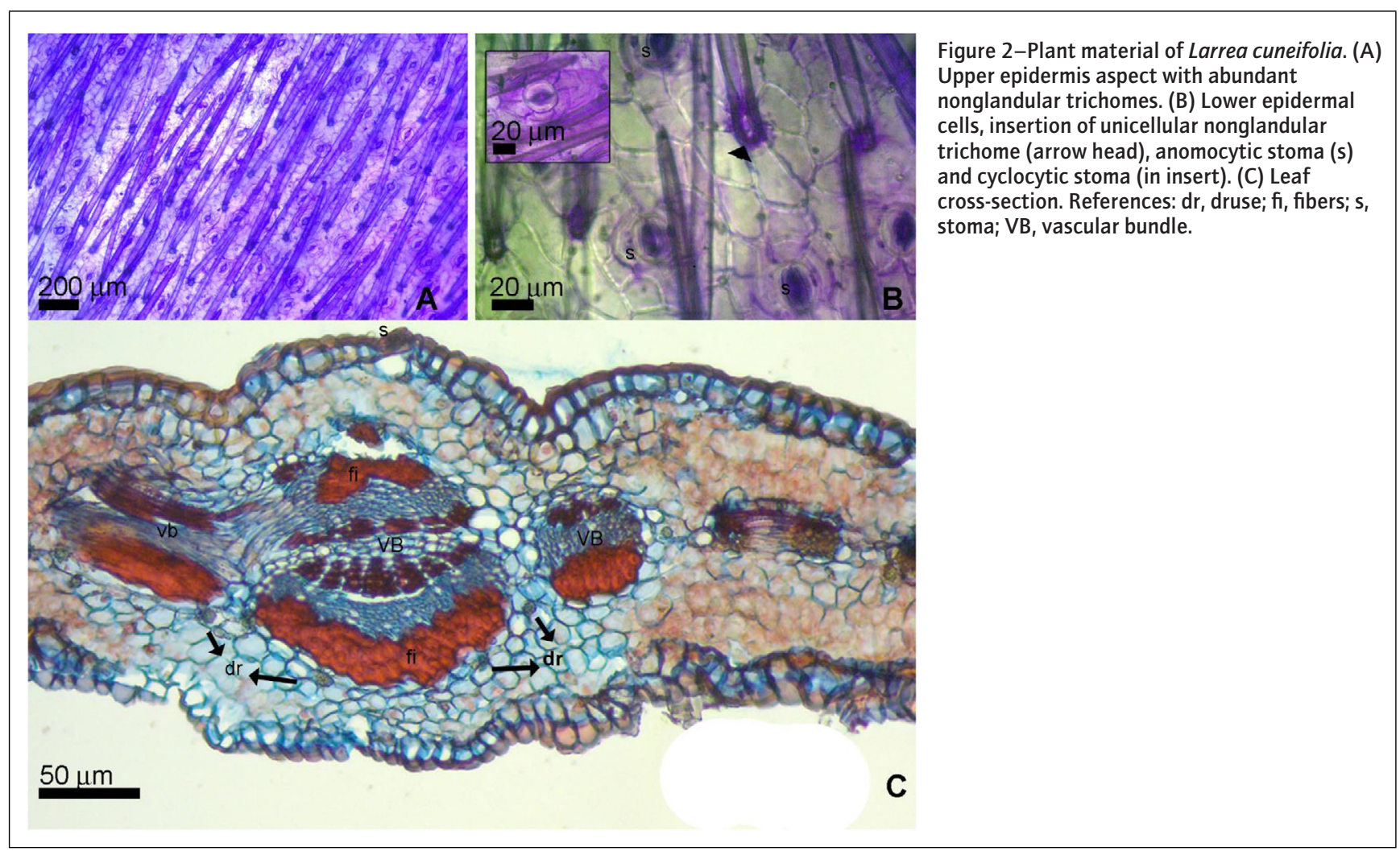

\subsection{HPLC-DAD analysis}

Phenolic compounds taken out from propolis and native plant species extracts were analyzed by the HPLC system (Water Corporation, Milford, MA) coupled to a diode array detector 2998 (220 to $540 \mathrm{~nm}$ ). A C-18 column (Water X-bridge) and a solvent system consisting of $9 \%$ acetic acid in water (A) and methanol (B) as follows: 90 to $43 \% \mathrm{~A}$ over $45 \mathrm{~min}$, followed by 43 to $0 \% \mathrm{~A}$, from 45 to $60 \mathrm{~min}$, and finally $0 \% \mathrm{~A}$, from 60 to $65 \mathrm{~min}$ were used. Detection of chemical component was in UV at $330 \mathrm{~nm}$. Empower ${ }^{\mathrm{TM}}$ software was used. Compounds were identified by retention time and UV spectra and confirmed by comparison with standards. Three replicates were performed for each sample.

\subsection{Fractionation of the PE}

Both the fractionation of $\mathrm{PE}$ and the identification of the most active fractions were performed according to Salas, Alberto, Zampini, Cuello, et al. (2016). The PE was permeated on Sephadex LH-20 by using methanol as a mobile phase. Seven fractions were obtained. The fractions were analyzed by HPLC-DAD according to Salas, Alberto, Zampini, Cuello, et al. (2016).

\subsection{Botanical analysis of propolis by using microscopic techniques}

For botanical analysis, samples of each raw propolis $(0.5 \mathrm{~g})$ were processed according to Salas, Mercado, Zampini, Ponessa, and Isla (2016). Botanical identification was made by comparing observed structures with both plant materials of $Z$. punctata, $L$. divaricata, and $L$. cuneifolia collected at the site where the beehives were located and with relevant literature (Álvarez et al., 2012; Lersten \& Curtis, 1996; Mercado et al., 2013, 2018; Moreno et al., 2015). Plant material was prepared according to Mercado et al. (2018) for conventional optic microscopy observations.
Observation of material was made under a Zeiss Axiolab optical microscope equipped with a Zeiss Axiocam ERc 5s digital camera and the measures were calculated by using the AxioVision Rel. 4.8 software.

\subsection{Palynological analysis of propolis}

The propolis were treated with $\mathrm{KOH}$, heated, centrifuged, resuspended in distilled water and filtered $(0.3 \mathrm{~mm}$ mesh filter) to remove large particles. Then, it was subjected to acetolysis (Erdtman, 1960). Samples were stained according to Wodehouse (1935). Pollen grain determination was carried out by comparison with reference collections of the Fundación Miguel Lillo (Palinoteca PAL-TUC) and/or using palynological Atlas (García, Reyes, \& Rios, 2012).

Observations and quantitative analysis were carried out with a Zeiss Axiolab Lab.A1 optical microscope equipped with a Zeiss Axiocam ERc 5s digital camera and AxioVision Rel. 4.8 and Zen 2 (Blue Edition) 2.0. software. The pollen was classified as dominant $(\mathrm{D})$, medium $(\mathrm{M})$, lower $(\mathrm{L})$, or trace $(\mathrm{T})$ according to following percentage of $>45 \% ; 16$ to $45 \% ; 3$ to $15 \%$, and $<3 \%$, respectively.

\subsection{Effect of propolis samples on enzymes of metabolic syndrome}

2.7.1 Effect on $\alpha$-glucosidase and $\alpha$-amylase. Enzymatic inhibition assays were performed according to Costamagna et al. (2016). The preincubation of the $\alpha$-glucosidase and $\alpha$-amylase with different concentrations of PE (6 to $50 \mu \mathrm{g} / \mathrm{mL}$ ) or positive (orlistat) and negative (solvent) controls was carried out at $4{ }^{\circ} \mathrm{C}$ for $10 \mathrm{~min}$. To start the reaction, the substrate, that is, $p$-nitrophenyl- $\alpha$-D-glucopyranoside or starch, respectively, was added. The reactions were incubated $15 \mathrm{~min}$ at $37^{\circ} \mathrm{C}$. Then, 


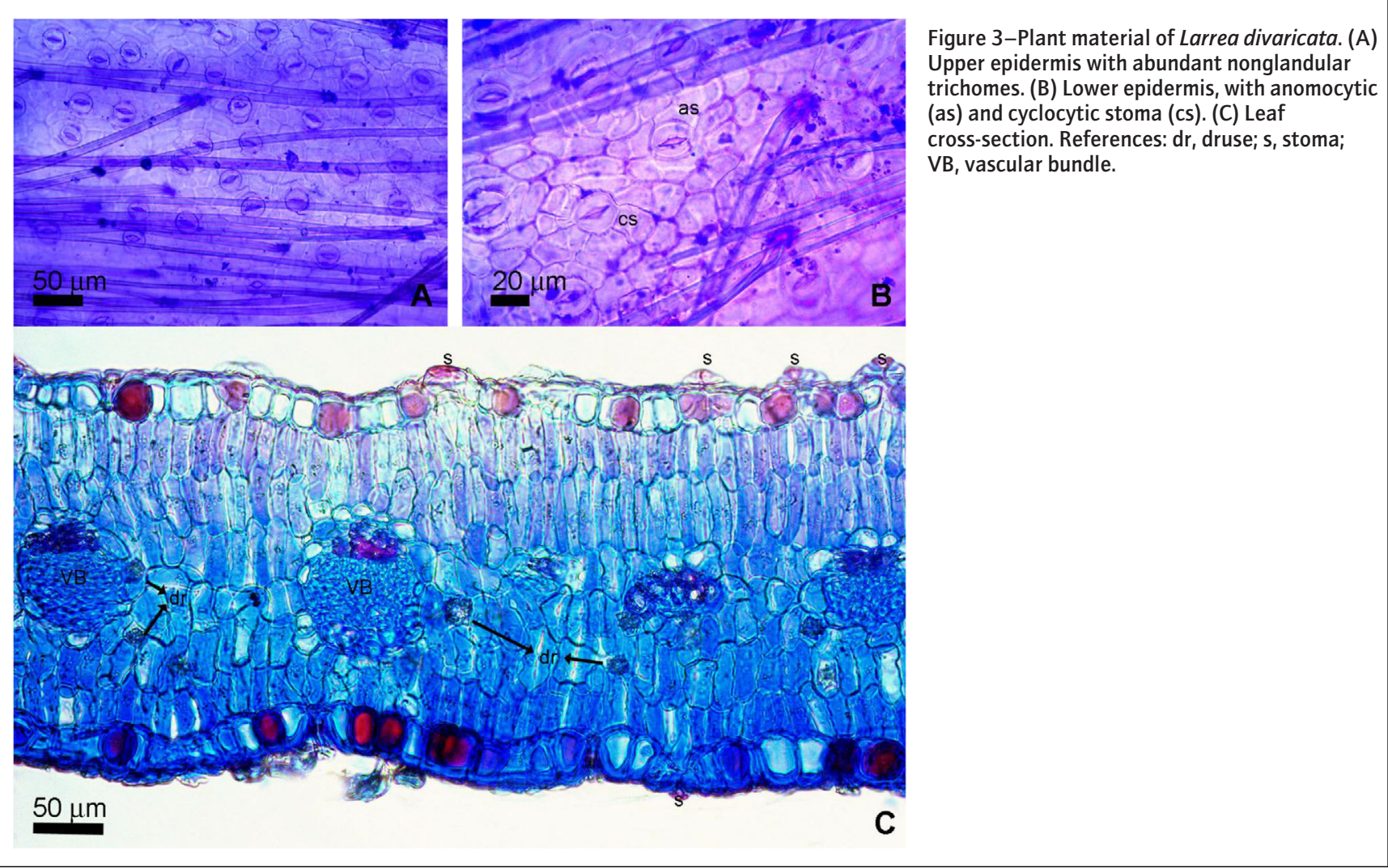

sodium carbonate or iodine solution, respectively were added. The absorbance was measured at $405 \mathrm{~nm}$ to $\alpha$-glucosidase assay or $640 \mathrm{~nm}$ to $\alpha$-amylase assay. The results were expressed as $\mathrm{IC}_{50} \mathrm{val}-$ ues, that is, $\mu \mathrm{g} / \mathrm{mL}$ of $\mathrm{PE}$ required to inhibit the enzyme activity by $50 \%$.

2.7.2 Effect on lipase. The effect of PE on lipase activity was assayed according to Costamagna et al. (2016) by using final concentration of PE between 6 and $48 \mu \mathrm{g} / \mathrm{mL}$, lipase and $p$-nitrophenylpalmitate as substrate. The amount of released $p$ nitrophenol at $37{ }^{\circ} \mathrm{C}$ was determined at $400 \mathrm{~nm}$. $\mathrm{IC}_{50}$ values were determined as $\mu \mathrm{g} / \mathrm{mL}$ of PE required to inhibit the enzyme activity by $50 \%$.

\subsection{Antioxidant activity of Argentinean propolis extracts}

Spectrophotometric methods were used. The scavenging percentage of each free radical and $\mathrm{H}_{2} \mathrm{O}_{2}$ with and without $\mathrm{PE}$ was calculated. Scavenge percentage versus concentration is plotted and the $\mathrm{SC}_{50}$ values are determined as the propolis concentration $(\mu \mathrm{g} / \mathrm{mL})$ necessary to scavenge $50 \%$ of free radicals or $\mathrm{H}_{2} \mathrm{O}_{2}$.

2.8.1 ABTS scavenging activity. The effect of $\mathrm{PE}$ on free radicals was determined according to Orqueda et al. (2017) by using different concentrations of PE (10 to $50 \mu \mathrm{g} / \mathrm{mL})$ in the presence of an $\mathrm{ABTS}^{\circ}+$ solution, with absorbance of 0.7 at $750 \mathrm{~nm}$. The percentage of scavenging was measured spectrophotometrically at $750 \mathrm{~nm}$ after $6 \mathrm{~min}$ of incubation.

2.8.2 Hydroxyl and superoxide radical scavenging activity. The effect of PE on superoxide radicals was determined according to Valentao et al. (2001) by using NADH/phenazine methosulfate (PMS)/nitro blue tetrazolium chloride (NBT) system and different concentrations of PE (10 to $300 \mu \mathrm{g} / \mathrm{mL})$. The reduction of NBT to the formazan blue chromogen by superoxide radicals was monitored spectrophotometrically at $560 \mathrm{~nm}$.
Hydroxyl radicals scavenging capacity was determined according to Chobot, Hadacek, Bachmann, Weckwerth, and $\mathrm{Ku}$ bicova (2016) by using the system 2-deoxy-D-ribose/ $\mathrm{FeCl}_{3} /$ EDTA $/ \mathrm{H}_{2} \mathrm{O}_{2}$ /ascorbic acid with and without PE. The mixture was incubated at $37^{\circ} \mathrm{C}$ for $60 \mathrm{~min}$. Then, 2-thiobarbituric acid was added and heated at $100{ }^{\circ} \mathrm{C}$ for $20 \mathrm{~min}$. The absorbance was measured at $532 \mathrm{~nm}$.

2.8.3 Hydrogen peroxide scavenging activity. The $\mathrm{H}_{2} \mathrm{O}_{2}$ scavenging activity was measured spectrophotometrically at $504 \mathrm{~nm}$ (Orqueda et al., 2017) by using the system $\mathrm{H}_{2} \mathrm{O}_{2} /$ phenol solution/4-aminoantipyrene/horseradish peroxidase with different concentrations of PE (20 to $100 \mu \mathrm{g} / \mathrm{mL})$.

2.8.4 Nitric oxide radical scavenging activity. The $\mathrm{PE}$ capacity to NO scavenge was performed according to Govindarajan et al. (2003) by using a concentration range between 20 and $200 \mu \mathrm{g} / \mathrm{mL}$. The assay mixture containing different concentrations of PE and sodium nitroprusside was incubated for $60 \mathrm{~min}$ at $37^{\circ} \mathrm{C}$. Then, Griess reagent was added and incubated for $15 \mathrm{~min}$ in the dark. The antioxidant capacity was measured spectrophotometrically at $550 \mathrm{~nm}$.

\subsection{Statistical analyses}

The statistical InfoStat (Student Version, 2011) software was used.

\section{RESULTS AND DISCUSSION}

\subsection{Botanical origin of propolis from Catamarca}

The quality of propolis and its botanical origin were determined by microscopic analyses to botanical identification of fragments of leaves or other debris left (Salas, Mercado, Zampini, Ponessa, and Isla , 2016). In the present study, according to microscopical 

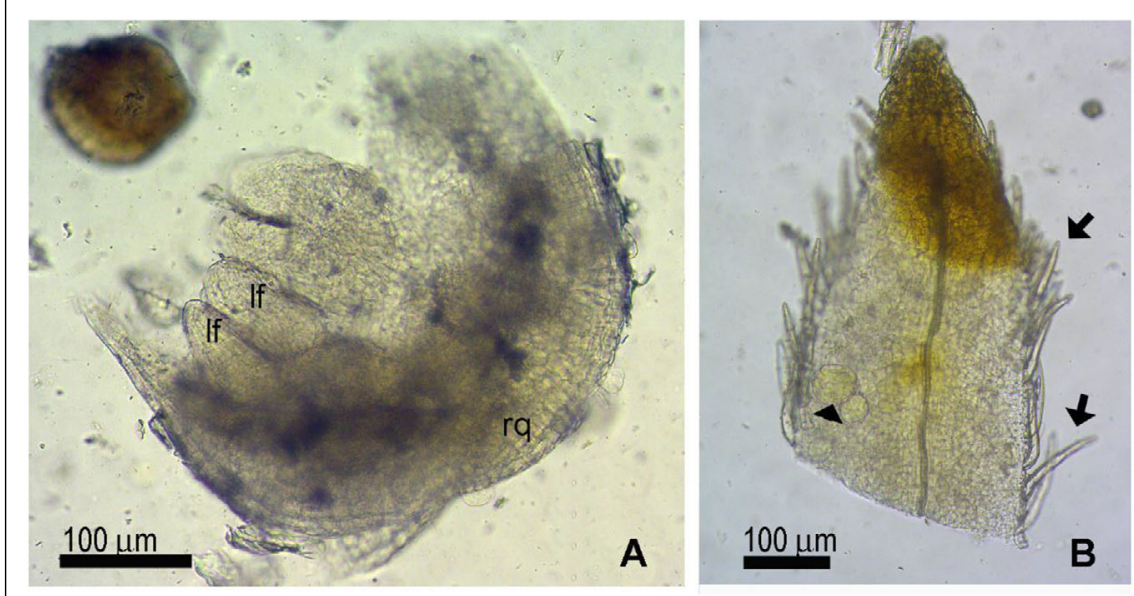

Figure 4-Botanical studies of propolis samples. Plant material identified as Zuccagnia punctata (Fabaceae). (A) Leaf primordia, with raquis ( $\mathrm{rq}$ ) and leaflets (If). (B) Leaflet fragment with nonglandular unicellular trichomes (arrow) with a thick cuticle and a blunt apex and rounded multicellular glands (arrow head). (C) Epidermal cells with straight anticlinal walls and striated cuticle. Cyclocytic stoma (s). (D) Multicellular capitate glandular trichomes. (E-F) Druses observed under white and polarized light (arrow head).
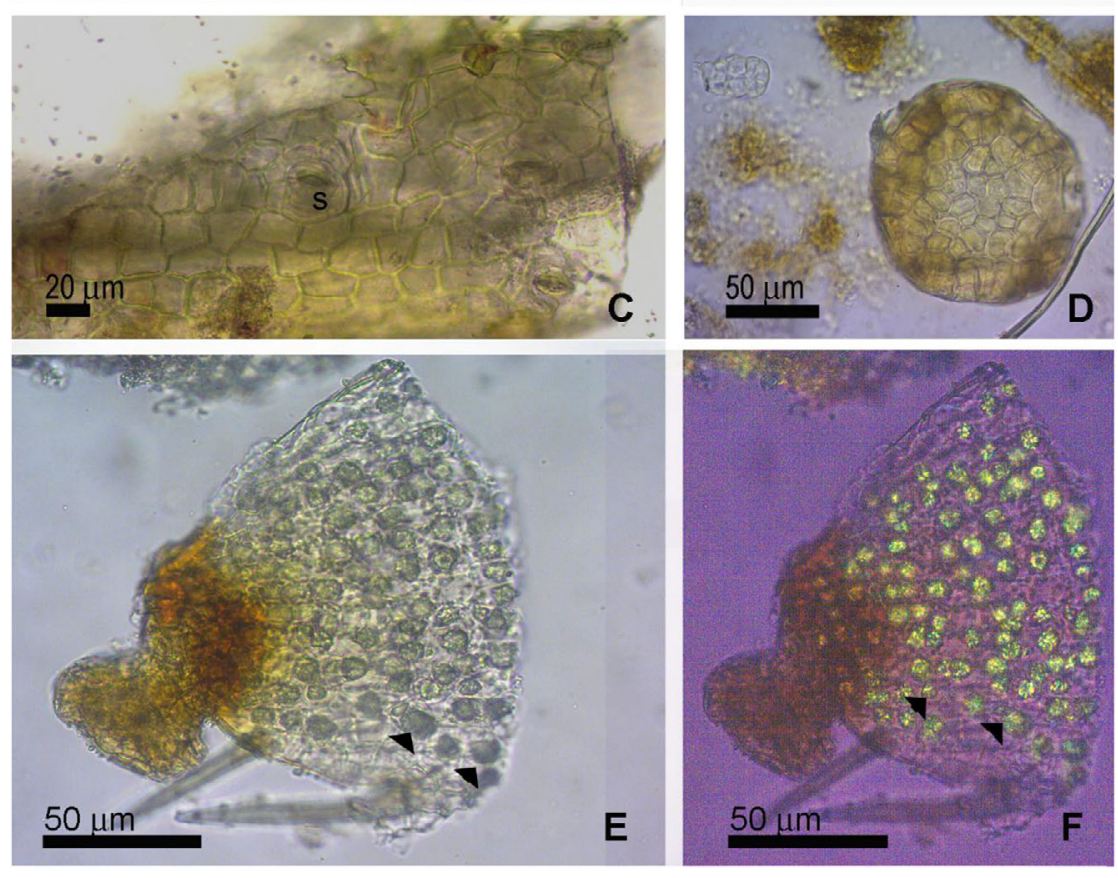

analyses, propolis samples from Catamarca, Argentina showed the presence of $Z$. punctata, Larrea sp., and nonidentified species in different ratios (Table 1). In 100\% of analyzed samples $Z$. punctata material was found (Table 1). Zuccagnia punctata and Larrea sp. were identified by comparison with plant samples. Aerial parts of $Z$. punctata, L. cuneifolia, and $L$. divaricata were analyzed by conventional microscopic techniques (Figures 1 to 3 ).

Microscopic analyses of propolis samples revealed the presence of $Z$. punctata, which was identified by the presence of compound leaf primordia with subopposite nanophyll leaflets (440.23 $\pm 167.87 \mathrm{~mm}$ long, $156.65 \pm 57.21 \mathrm{~mm}$ lat) with acuminate apex, rounded, symmetrical base, and entire margin (Figure 4A), free leaflet fragments with spherical to oval sunken capitate multicellular glandular trichomes $(163.75 \pm 93.12 \mu \mathrm{m}$ of diameter) (Figure 4B) and unicellular nonglandular trichomes $(299.87 \pm 10.73$ and $45.21 \pm 4.21 \mu \mathrm{m})$ (Figure 4B) arranged on the adaxial base of the foliar surface and on the foliar margins (368.44 and $44.21 \mu \mathrm{m}$ ), leaflet epidermal cells with straight anticlinal walls (Figure 4B and 4C), cyclocytic stoma, rarely paracytic or anomocytic on both epidermal surfaces $(32.51 \pm 2.15 \mu \mathrm{m}$ long and $27.32 \pm 2.58 \mu \mathrm{m}$ lat) (Figure 4C) and druses in the mesophyll (Figure 4E and 4F). Isolated multicelullar glandular trichomes were also observed (Figure 4D). These features respond to those previously described for Z . punctata (Álvarez et al., 2012; Lersten \& Curtis, 1996; Mercado et al., 2013). Large deviations from mean values found in the longitude of leaflets and diameter of glandular trichomes could be attributed to different maturation stages.

Larrea sp. structures were found only in $20 \%$ of samples (CI). Larrea samples were identified by leaf epidermal segments characterized by epidermal cells with straight anticlinal walls, cyclocytic and anomocytic stoma $(20.54 \pm 3.25 \mu \mathrm{m}$ long and $27.80 \pm 4.55 \mu \mathrm{m}$ lat) (Figure 5A), abundant unicellular trichomes with acute apex $(234.45 \pm 145.55 \mu \mathrm{m}$ long $)$ with the epidermal cells arranged in groups of 4 to 6 converging toward the base of the trichome (Figure 5B), features previously described for these species by Mercado et al. (2018).

In propolis samples from Santa María, Catamarca (C-III) a nonidentified species and $Z$. punctata structures were found. The predominant nonidentified species was characterized by the presence 


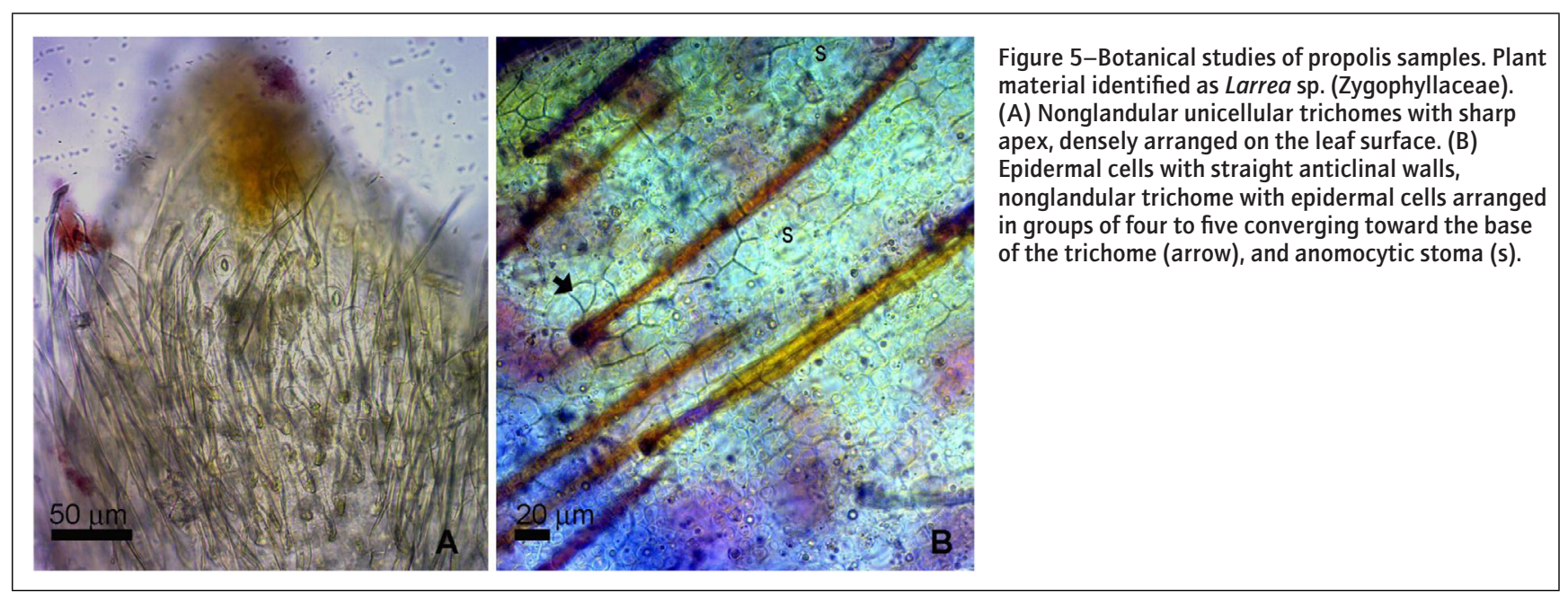

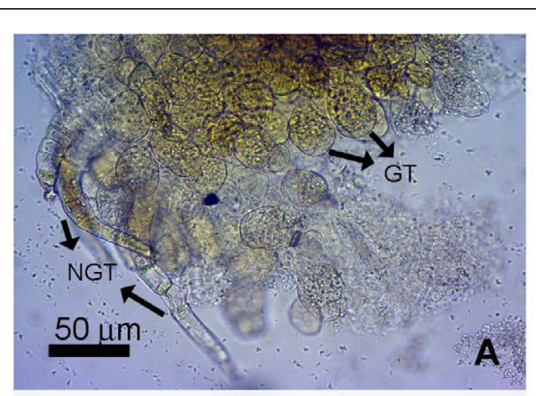
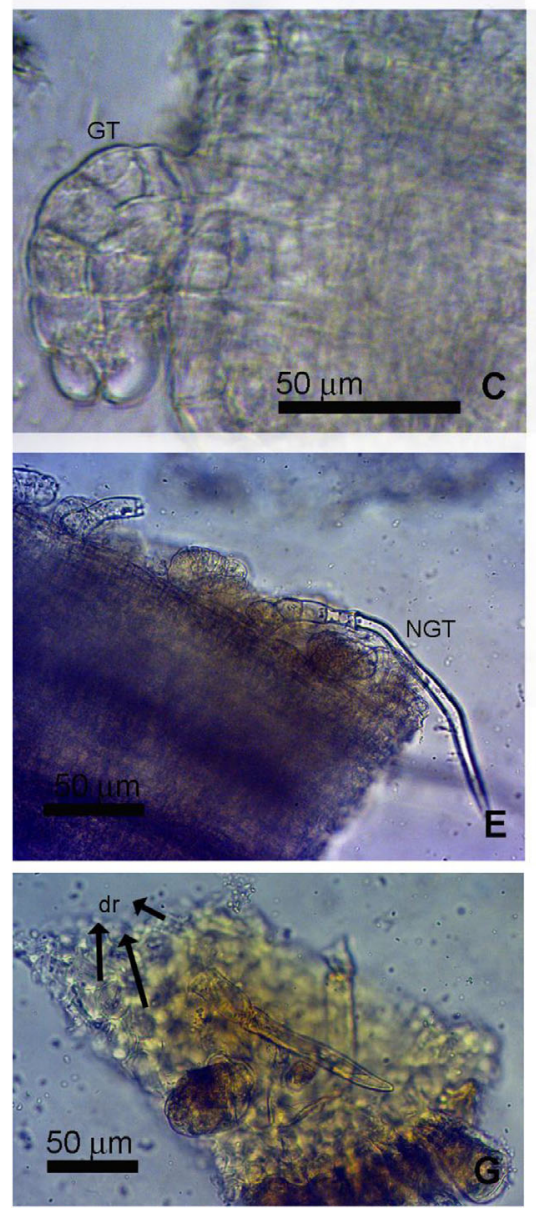
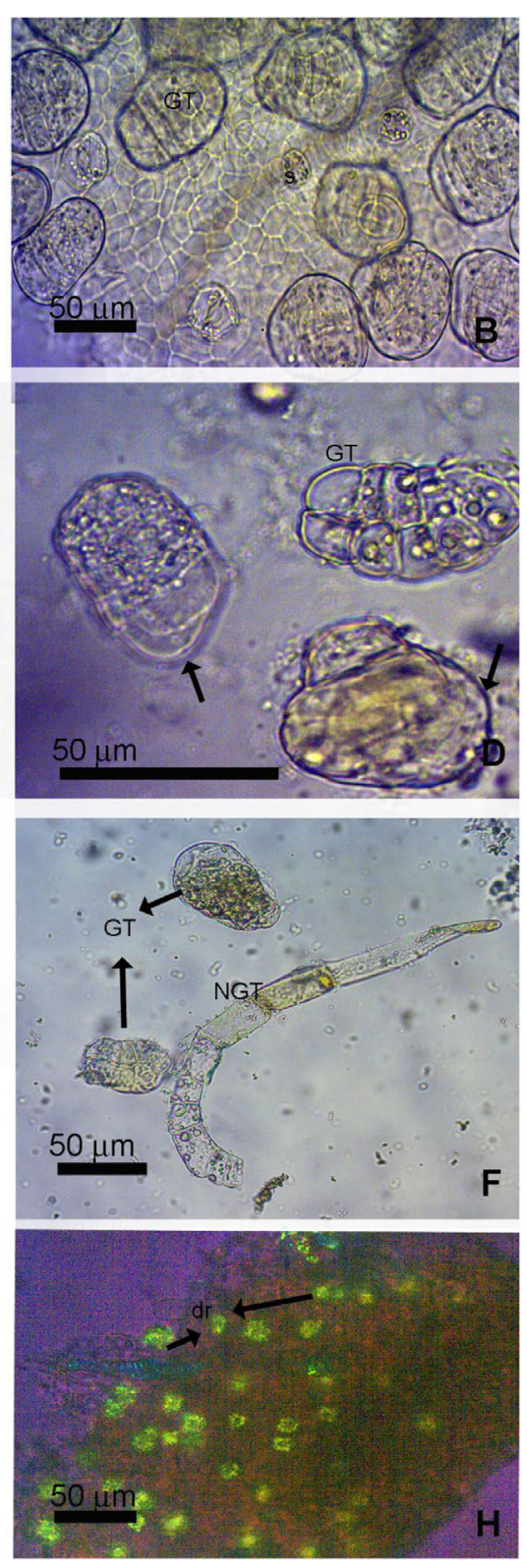

Figure 6-Botanical studies of propolis samples. Nonidentified material. (A) Foliar fragment aspect with uniseriate nonglandular trichomes (NGT), biseriate glandular trichomes (GT). (B) Epidermal fragment, epidermal cells with straight anticlinal walls, anomocytic stomata (s) and biseriate glandular trichomes (GT). (C-D) Free multicellular biseriated glandular trichomes (GT), sometimes with the cuticle slightly expanded (arrow). (E-F)

Multicellular uniseriate nonglandular trichomes with an elongated apical cell. (G) Druses (dr) observed under white and $(H)$ polarized light. 
Table 2-Percentage of pollen found in samples of propolis from Catamarca.

\begin{tabular}{|c|c|c|c|c|c|}
\hline C-I & $\%$ & C-II & $\%$ & C-III & $\%$ \\
\hline Prosopis & 29.6 & Asteraceae & 15.4 & Schinus & 19.7 \\
\hline Myrtaceae & 12.4 & Descurainia & 14.2 & Prosopis & 18.7 \\
\hline Mimosa & 8.7 & Gomphrena & 13.9 & Ligustrum & 12.1 \\
\hline Larrea & 8.4 & Brassicaceae & 10.6 & Larrea & 11.1 \\
\hline Asteraceae & 8 & Schinus & 10.2 & Myrtaceae & 9.6 \\
\hline Ricinus & 6.2 & Prosopis & 9.9 & Asteraceae & 8.6 \\
\hline Schinus & 3.6 & Myrtaceae & 5 & Brassicaceae & 7 \\
\hline Amaranthaceae & 2.9 & Larrea & 4 & Salix & 3.5 \\
\hline Cactaceae & 2.9 & Amaranthaceae & 4.4 & Papaveraceae & 3.5 \\
\hline Monocotiledonea & 2.5 & Monocotiledonea & 4 & Plantago & 1.01 \\
\hline Acacia & 2.2 & Loranthaceae & 3.7 & Gomphrena & 1.01 \\
\hline Descurainia & 1.45 & Taraxacum & 2.2 & Celtis & 1.01 \\
\hline Poacea & 1 & Zuccagnia & 1.5 & Loranthaceae & 0.5 \\
\hline Celtis & 1 & Cactaceae & 0.7 & Acacia & 0.5 \\
\hline Ligustrum & 1 & & & Zuccagnia & 0.5 \\
\hline Fumariaceae & 1 & & & Descurainia & 0.5 \\
\hline Ambrosia & 1 & & & Tecoma & 0.5 \\
\hline NID* & 0.7 & & & Clematis & 0.5 \\
\hline Tecoma & 0.7 & & & Pinaceae & 0.5 \\
\hline Malvaceae & 0.7 & & & & \\
\hline Brassicaceae & 0.7 & & & & \\
\hline Rubiaceae & 0.36 & & & & \\
\hline Polygonum & 0.36 & & & & \\
\hline Mutisia & 0.36 & & & & \\
\hline Loranthaceae & 0.36 & & & & \\
\hline Lamiaceae & 0.36 & & & & \\
\hline Ephedra & 0.36 & & & & \\
\hline Chorisia & 0.36 & & & & \\
\hline
\end{tabular}

Samples from El Rincon (C-I) and Santa María (C-II, C-III). NID* Non identified

of amphistomatic leaf fragments, epidermal cells with straight anticlinal walls, anomocytic stomata $(15.30 \pm 4.71 \mu \mathrm{m}$ long and $18.33 \pm 5.32 \mu \mathrm{m}$ lat), multicellular biseriated glandular trichomes with a slightly expanded cuticle $(69.87 \pm 21.29 \mu \mathrm{m}$ long), multicellular uniseriated nonglandular trichomes (4 to
8 cells, $174.91 \pm 49.12 \mu \mathrm{m}$ long) with an elongated apical cell (Figure 6). In all samples, remains of pollen, spores, insect integument, and bristles were observed. Calcium oxalate druses were observed with polarized light.

According with these results, the botanical origin could mainly be ascribed to $Z$. punctata.

\subsection{Melissopalynological studies}

Furthermore, pollen grains in propolis samples could provide further evidence for the vegetation and the geographical origin of propolis (Guzelmeric et al., 2018). According to pollen analysis, 28 pollinic types corresponding to 29 families were identified in propolis samples from Catamarca (Table 2, Figure 7). Melissopalynological studies demonstrated that Fabaceae, Asteraceae, Zygophyllaceae, Amaranthaceae, and Brassicaceae were the only families represented by more than one pollen type. Ambrosia sp. (Asteraceae) and Descurainia sp. (Brassicaceae) were considered separately because of the abundance of their pollen grains and the accuracy for their determination.

Prosopis sp., Larrea sp., Schinus sp., Asteraceae, Myrtaceae, Brassicaceae, and Loranthacea pollen types were present in different ratios in the samples analyzed. This association indicates that the samples belong to the Monte of Sierras and Bolsones ecoregion (Cabrera, 1976; Morello et al., 2012).

The number of pollen types per sample varies between 27 and 14. C-I and C-III samples showed the highest diversity of pollen types and the highest percentages of each one (Prosopis sp., Larrea sp., Schinus sp.). C-II differs from the other samples with the highest amounts of Asteraceae, Descurainia sp. (Brassicaceae), and Gomphrena sp. (Table 2).

Pollen percentages ranged between 15.4 and 30\% (Prosopis sp., Schinus sp., and Asteraceae) or slightly below 15.4\% (Larrea sp., Myrtaceae, Descurrainia sp., and Gomphrena sp.) (Table 2).

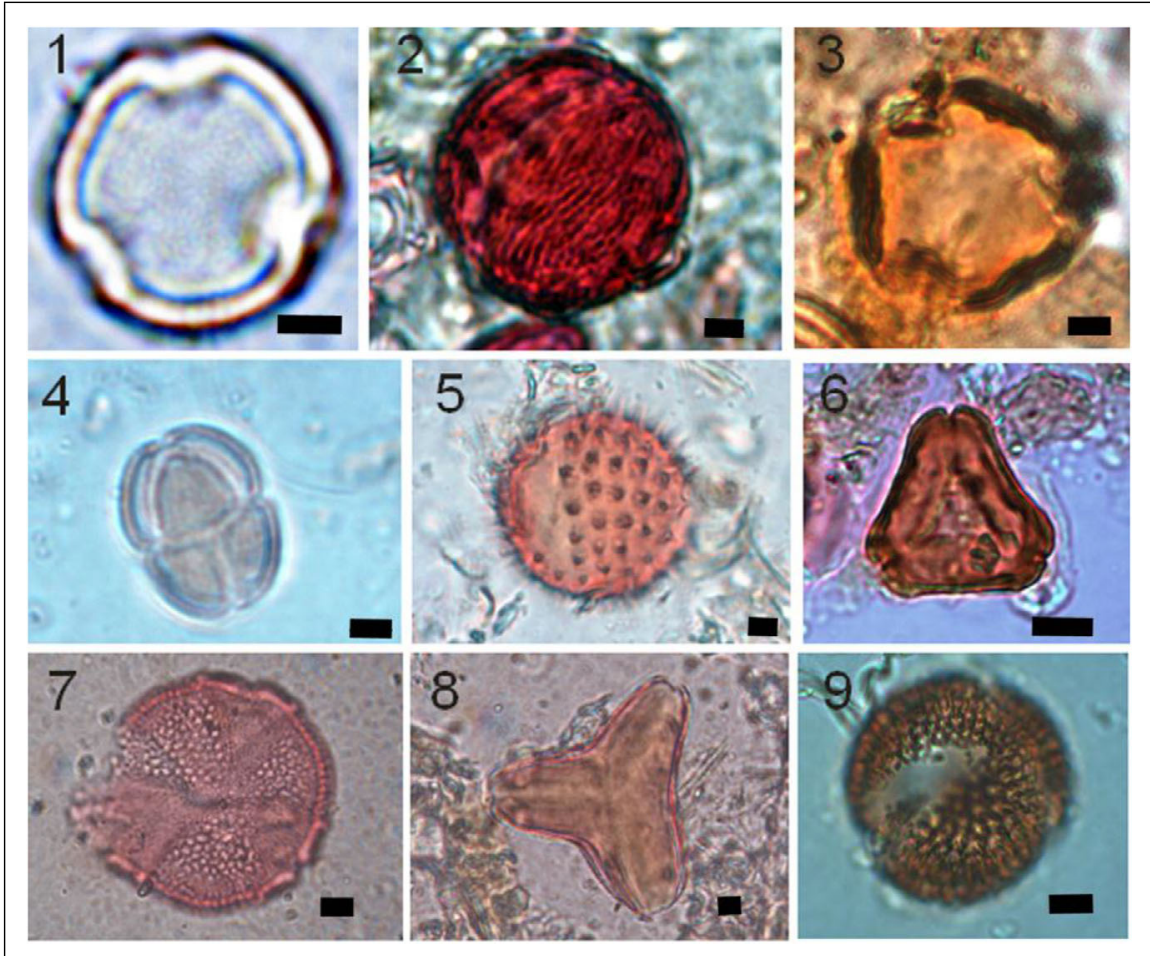

Figure 7-Main pollen types present in propolis samples. (1) Larrea sp. polar view. (2) Schinus sp. equatorial view. (3) Prosopis sp. polar view. (4) Mimosa sp. (Asteraceae) equatorial view. (5 and 6) Myrtaceae polar view. (7) Zuccagnia punctata polar view. (8) Loranthaceae polar view. (9) Brassicaceae subequatorial view. Scale $5 \mu \mathrm{m}$. 
Argentinean propolis as food ingredient...

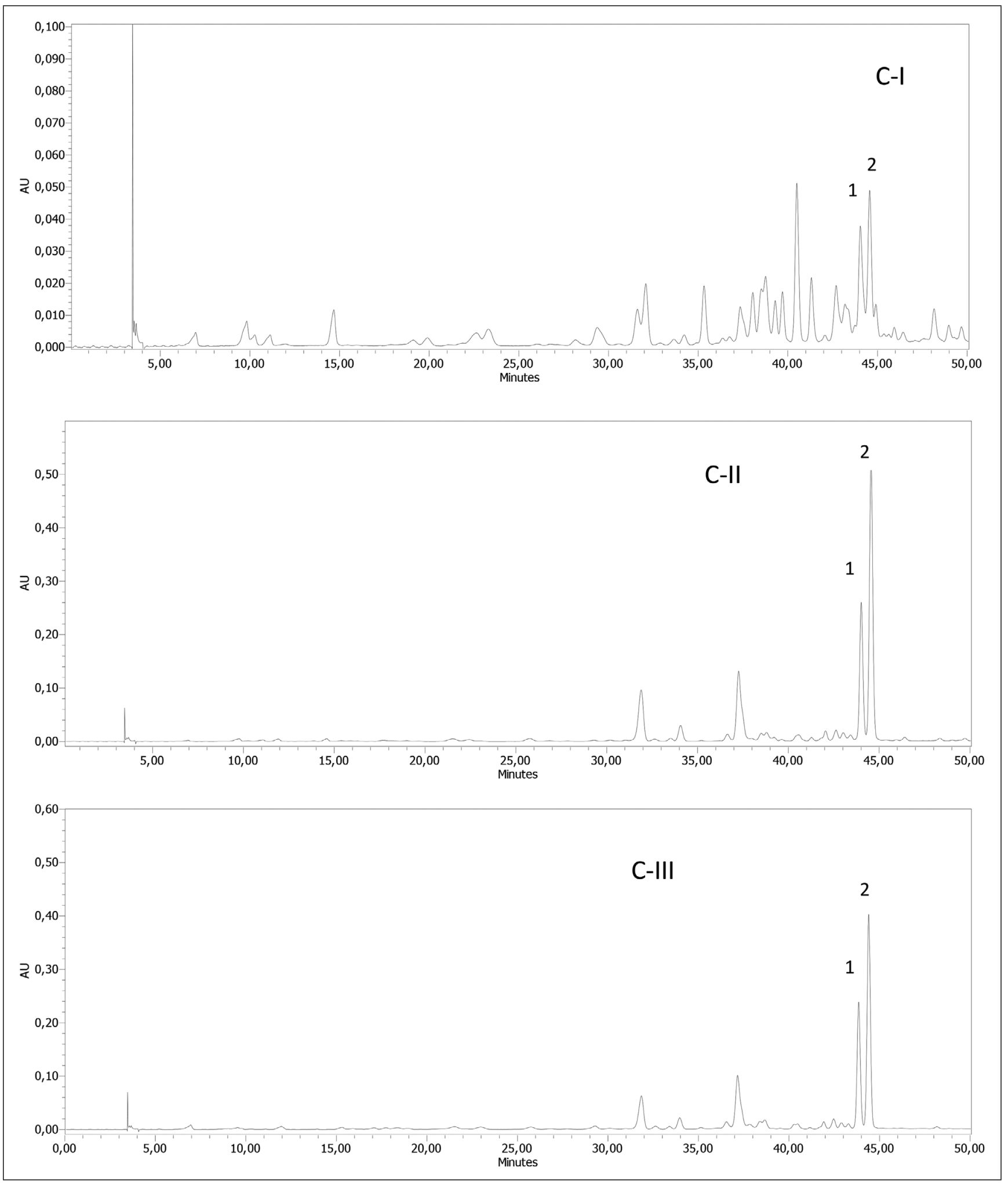

Figure 8-HPLC profiles of propolis extracts from Catamarca (330 nm). (A) Sample C-I. (B) Sample C-II. (C) Sample C-III. (1) 2',4'-dihydroxychalcone. (2) $2^{\prime}, 4^{\prime}$-dihydroxy-3'-methoxychalcone. 
Table 3-Inhibitory activity of propolis and $Z$. punctata extracts from Catamarca and isolated chalcones on enzymes related to metabolic syndrome.

\begin{tabular}{lccc}
\hline Samples & $\begin{array}{c}\text { IC }_{\mathbf{5 0}} \text { Lipase } \\
(\boldsymbol{\mu g} / \mathbf{m L})\end{array}$ & $\begin{array}{c}\text { IC }_{\mathbf{5 0}} \\
\boldsymbol{\alpha} \text {-glucosidase } \\
(\boldsymbol{\mu g} / \mathbf{m L})\end{array}$ & $\begin{array}{c}\text { IC }_{\mathbf{5 0}} \boldsymbol{\alpha} \text {-amylase } \\
(\boldsymbol{\mu} \mathbf{g} / \mathbf{m L})\end{array}$ \\
\hline C-I & $13 \pm 3^{\mathrm{a}}$ & $11 \pm 2^{\mathrm{b}}$ & $41 \pm 1^{\mathrm{a}}$ \\
C-II & $25 \pm 2^{\mathrm{b}}$ & $12 \pm 1^{\mathrm{b}}$ & $40 \pm 2^{\mathrm{a}}$ \\
C-III & $28 \pm 1^{\mathrm{b}}$ & $7 \pm 0^{\mathrm{a}}$ & $37 \pm 2^{\mathrm{a}}$ \\
Zp & $23 \pm 2^{\mathrm{b}}$ & $14 \pm 1^{\mathrm{b}}$ & $42 \pm 3^{\mathrm{a}}$ \\
DHC & $14 \pm 0^{\mathrm{a}}$ & $8 \pm 0^{\mathrm{a}}$ & $46 \pm 0^{\mathrm{a}}$ \\
DHMC & $16 \pm 0^{\mathrm{a}}$ & $8 \pm 1^{\mathrm{a}}$ & $48 \pm 1^{\mathrm{a}}$ \\
\hline
\end{tabular}

Samples from El Rincon (C-I) and Santa María (C-II, C-III). DHC, 2' $4^{\prime}$-dihydroxychalcone; DHMC, 2', 4'-dihydroxy-3'-methoxychalcone; Zp, Zuccagnia punctata extract; $\mathrm{IC}_{50}$, inhibitory concentration of $50 \%$ enzymatic activity. Values with a common letter in the same column are not significantly different $(P \leq 0.05)$.

Minor pollen types ranged between 3 and 15\%, while pollen traces $(\mathrm{T})$ were present in less than $3 \%$ of each sample, and were represented by native species as $Z$. punctata and Acacia praecox (Fabaceae), L. divaricata and L. cuneifolia (Zigophyllaceae), and Psitacanthus sp. (Lorantaceae). The high amounts of Ligustrum sp. in C-III, which is not a native species of the region, would indicate a degree of vegetation alteration probably due to human action (Table 2). The results are in agreement with previous reports that showed a large number of plant species providing nectar and pollen to honeybees; however, only a few plant species are resin sources for propolis production (Salatino \& Salatino, 2017).

Our results suggested that the differences found in botanical remains compared to palynological remains in Catamarca propolis may be due to the bees selected tender parts, that is, primordial and apical buds, of resinous shrubs, such as $Z$. punctata, for the production of propolis and other plants with flowers available for honey production, although the melissopalynological analysis is not determinant of the propolis botanical origin, it provides important information about the flora surrounding the hive.

\subsection{Chemical characterization}

To confirm the botanical origin of propolis samples coming from the ecoregion of Monte of Sierras and Bolsones, Catamarca, a chemical characterization of PEs was carried out and compared with extracts of three jarilla species. Predominant chemical components of the propolis and $Z$. punctata extracts were (1) $2^{\prime}, 4^{\prime}$ dihydroxychalcone and (2) 2',4'-dihydroxy-3'-methoxychalcone (Figure 8). Both compounds were previously considered as chemical markers to analyzed Zuccagnia type propolis samples (Salas, Mercado, Zampini, Ponessa, \& Isla, 2016).

Chemical components, such as nordihydroguaiaretic acid, the major chemical compound of both Larrea species were not found in the PEs under study.

According with the results, the botanical origin of propolis samples from the province of Catamarca could be $Z$. punctata. Thus, we propose to name this propolis as a Zuccagnia-type propolis.

\subsection{Inhibitory capacity of enzymes related to metabolic syndrome}

The chalcone-enriched PE (C-I, C-II, and C-III) and Z. punctata extract showed a strong inhibitory activity for $\alpha$-glucosidase and lipase, followed by $\alpha$-amylase (Table 3 ). However, $2^{\prime}, 4^{\prime}-$ dihydroxychalcone and $2^{\prime}, 4^{\prime}$-dihydroxy-3'-methoxychalcone isolated from PEs were most active, inhibiting lipase and $\alpha$-glucosidase enzymes (Table 3 ). Other authors reported that chalcones are potent $\alpha$-glucosidase, $\alpha$-amylase, and lipase inhibitors (Bale et al., 2018; Cai et al., 2017; Mahapatra, Asati, \& Bharti, 2015, Mahapatra, \& Barthi, 2016).

Cai et al. (2017) reported that the hydroxyl chalcones showed a higher activity on $\alpha$-glucosidase than methoxylated chalcones and that the position of hydroxyl groups in chalcones is another key factor for their $\alpha$-glucosidase inhibitory activities, probably due to its H-bond donor effect. The inhibition of amylase might be due to the availability of the electron-accepting groups and electron-donating groups (Bale et al., 2018). The chalcones, previously considered as chemical markers in Zuccagnia-type propolis from Tucuman and $Z$. punctata extracts could be responsible of inhibitory activity of enzymes related to the metabolic syndrome in propolis from Catamarca, Argentina.

\subsection{Antioxidant capacity}

The reactive species of oxygen/nitrogen (ROS/RNS) as hydroxyl radical $\left(\mathrm{HO}^{\circ}\right)$, hydrogen peroxide $\left(\mathrm{H}_{2} \mathrm{O}_{2}\right)$, superoxide radical $\left(\mathrm{O}_{2}{ }^{-}\right)$, and nitric oxide $\left(\mathrm{NO}^{\circ}\right)$ are a health hazard, since they are able to oxidize proteins, nucleic acids, and lipids. These free radicals contribute to aging, mutagenesis, carcinogenesis, Parkinson's or Alzheimer's, inflammatory process (Kurek-Górecka et al., 2014).

In the present study, free-radical scavenging capacity of PE from Catamarca was determined. The C-II and C-III samples from Santa María were more active as $\mathrm{HO}^{\circ}$ scavengers $\left(\mathrm{SC}_{50}\right.$ values of 17 and $16.5 \mu \mathrm{g} / \mathrm{mL}$, respectively) than C-I sample from El Rincón $\left(\mathrm{SC}_{50}\right.$ values of $37 \mu \mathrm{g} / \mathrm{mL}$ ). However, C-I showed the highest power as $\mathrm{H}_{2} \mathrm{O}_{2}$ scavenger (Table 4).

On the other hand, $\mathrm{O}_{2}{ }^{-}-$plays an important role in redox cell signaling and development of pathophysiological conditions (Pistón et al., 2014). C-II and C-III samples were the most active as $\mathrm{O}_{2}{ }^{\circ-}$ scavengers with $\mathrm{SC}_{50}$ values of 115 and $205 \mu \mathrm{g} / \mathrm{mL}$, respectively. C-I also showed a notable capacity to scavenge nitrogenreactive species as $\mathrm{NO}^{\circ}$ (Table 4 ).

All samples showed effective scavenging activity on ABTS with $\mathrm{SC}_{50}$ values between 29.5 and $33 \mu \mathrm{g} / \mathrm{mL}$ (Table 4). The antioxidant capacity of $Z$. punctata extracts was also demonstrated in previous reports (Carabajal, Isla, \& Zampini, 2017, Carabajal, Isla, Borsarelli, \& Zampini, 2020; Carabajal, Perea, Isla, \& Zampini, 2020; Isla et al., 2016; Moreno et al., 2018). Other authors also evidenced scavenging activity of Argentinian PE on ABTS and DPPH radical (Nieva Moreno, Isla, Vattuone, \& Sampietro, 2000, 2005; Salas et al., 2016a; Solórzano et al., 2012).

Table 4-Antioxidant activity of propolis extracts from Catamarca.

\begin{tabular}{lccccc}
\hline Propolis extract & $\mathbf{S C}_{\mathbf{5 0}}\left(\mathbf{A B T S}^{\bullet+}\right)(\boldsymbol{\mu g} / \mathbf{m L})$ & $\mathbf{S C}_{\mathbf{5 0}}\left(\mathbf{H O}^{\bullet}\right)(\boldsymbol{\mu g} / \mathbf{m L})$ & $\mathbf{S C}_{\mathbf{5 0}}\left(\mathbf{O}_{\mathbf{2}}{ }^{-\boldsymbol{}}\right)(\boldsymbol{\mu g} / \mathbf{m L})$ & $\mathbf{S C}_{\mathbf{5 0}}\left(\mathbf{H}_{\mathbf{2}} \mathbf{O}_{\mathbf{2}}\right)(\boldsymbol{\mu g} / \mathbf{m L})$ & $\mathbf{S C}_{\mathbf{5 0}}(\mathbf{N O})(\boldsymbol{\mu g} / \mathbf{m L})$ \\
\hline C-I & $32.2 \pm 0.7^{\mathrm{a}, \mathrm{b}}$ & $37.0 \pm 1.0^{\mathrm{b}}$ & $290 \pm 40^{\mathrm{c}}$ & $39.00 \pm 0.03^{\mathrm{a}}$ & $50.00 \pm 0.01^{\mathrm{a}}$ \\
C-II & $29.5 \pm 1.7^{\mathrm{a}}$ & $17.0 \pm 1.0^{\mathrm{a}}$ & $115 \pm 10^{\mathrm{a}}$ & $58.50 \pm 0.02^{\mathrm{b}}$ & $76.40 \pm 0.06^{\mathrm{b}}$ \\
C-III & $33.7 \pm 1.2^{\mathrm{b}}$ & $16.5 \pm 1.5^{\mathrm{a}}$ & $205 \pm 25^{\mathrm{b}}$ & $92.00 \pm 0.02^{\mathrm{c}}$ & $104.50 \pm 0.02^{\mathrm{c}}$ \\
\hline
\end{tabular}

Samples from El Rincon (C-I) and Santa Marí (C-II, C-III). SC 50 , scavenging concentration of $50 \%$ of free radicals, NO, and hydrogen peroxide. Values with a common letter in the same column are not significantly different $(P \leq 0.05)$. 


\section{CONCLUSIONS}

According to the botanical and chemical analysis, Z. punctata is the major supplier of resins for the production of propolis from beehives located in the Monte of Sierras and Bolsones ecoregion, in Catamarca, Argentina, while the palynological profiles suggested that bees selected other plants with flowers for their food and honey production. This study is the first report that indicates that propolis samples from Argentina are effective to inhibit enzymes related to the metabolic syndrome and to free-radical scavenge activity. The results suggest that Zuccagnia-type propolis may be both a food supplement to control the metabolic syndrome and a potent antioxidant.

\section{CONFLICTS OF INTEREST}

The authors have stated that there is no conflict of interest.

\section{AUTHOR CONTRIBUTIONS}

Conceived and designed the experiments: MII, ICZ.

Performed the experiments: AS, EO, MIM, FCU, MEG, JP, MAA, GP, LM, ICZ, MII.

Analyzed the data: MII, AS, MIM, ICZ, MEG, JP, GP, LM, MAA, ICZ.

Wrote the paper: MII, MIM, ICZ, AS.

Conceived and initiated the project: MII.

\section{ACKNOWLEDGMENTS}

The authors would like to thank the following for their financial support Secretaría de Ciencia, Arte e Innovación Tecnológica (SCAYT, PIUNT), Argentina, Agencia Nacional de Promoción Científica y Tecnológica (ANPCyT) PICT 2014 Number 3136 and PICT 2017 Number 4436 and Consejo Nacional de Investigaciones Científicas y Técnicas (CONICET, PUE 20180011), Argentina.

\section{REFERENCES}

Agüero, M. B., González, M., Lima, B., Svetaz, L., Sánchez, M., Zacchino, S., ... Tapia, A. (2010). Argentinean propolis from Zuccagnia punctata Cav. (Caesalpinieae) exudates: Phytochemical characterization and antifungal activity. Journal of Agricultural and Food Chemistry, 58 194-201. https://doi.org/10.1021/jf902991t

Agüero, M. B., Svetaz, L., Baroni, V., Lima, B., Luna, L., Zacchino, S., ... Tapia, A. (2014). Urban propolis from San Juan province (Argentina): Ethnopharmacological uses and antifungal activity against Candida and dermatophytes. Industrial Crops and Products, 57, 166-173. https://doi.org/10.1016/j.indcrop.2014.03.009

Agüero, M. B., Svetaz, L., Sánchez, M., Luna, L., Lima, B., López, M. L., ... Feresin, G. E. (2011). Argentinean Andean propolis associated with the medicinal plant Larrea nitida Cav. (Zygophyllaceae). HPLC-MS and GC-MS characterization and antifungal activity. Food and Chemical Toxicology, 49, 1970-1978. https://doi.org/10.1016/j.fct.2011.05.008

Álvarez, S. L., Cortadi, A., Juárez, M. A., Petenatti, E., Tomi, F., Casanova, J., . . . Vila, R. (2012) (-)-5,6-dehydrocamphor from the antifungal essential oil of Zuccagnia punctata. Phytochemistr Letters, 5, 194-199. https://doi.org/10.1016/j.phytol.2011.12.008

Bale, A. T., Khan, K. M., Salar, U., Chigurupati, S., Fasina, T., Ali, F., \& Perveen, S. (2018). Chalcones and bis-chalcones: As potential $\alpha$-amylase inhibitors; synthesis, in vitro screening, and molecular modelling studies. Bioorganic Chemistry, 79, 179-189. https://doi.org/10.1016/j.bioorg.2018.05.003

Cabrera, A. L. (1976). Regiones fitogeográficas argentinas. Enciclopedia Argentina de agricultura y jardinería. Tomo II. Ed. Acme. Buenos Aires, Argentina.

Cai, C. Y., Rao, L., Rao, Y., Guo, J. X., Xiao, Z. Z., Cao, J. Y., \& Wang, B. (2017). Analogues of xanthone-chalcones and bis-chalcones as $\alpha$-glucosidase inhibitors and anti-diabetes candidates. European Journal of Medicinal Chemistry, 130, 51-59. https://doi.org/10.1016/j.ejmech.2017.02.007

Carabajal, M. P. A., Isla, M. I., Borsarelli, C. D., \& Zampini, I. C. (2020). In fluence of in vitro gastro-duodenal digestion on the antioxidant activity of single and mixed three "Jarilla" species infusions. Journal of Herbal Medicine, 19, 100296. https://doi.org/10.1016/j.hermed.2019.100296

Carabajal, M. P. A., Isla, M. I., \& Zampini, I. C. (2017). Evaluation of antioxidant and antimutagenic activity of herbal teas from native plants used in traditional medicine in Argentina. South African Journal of Botany, 110, 258-265. https://doi.org/10.1016/j.sajb.2016.10.006

Carabajal, M. P. A., Perea, M. C., Isla, M. I., \& Zampini, I. C. (2020). The use of jarill native plants in a Diaguita-Calchaquí indigenous community from northwestern Argentina: An ethnobotanical, phytochemical and biological approach. Journal of Ethnopharmacology, 247, 112258. https://doi.org/10.1016/j.jep.2019.112258

Chobot, V., Hadacek, F., Bachmann, G., Weckwerth, W., \& Kubicova, L. (2016). Pro and antioxidant activity of three selected flavan type flavonoids: Catechin, eriodictyol and taxifolin. International Journal of Molecular Sciences, 17(12), 1986-1995. https://doi.org/10.3390/ijms17121986
Coelho, J., Falcao, S. I., Vale, N., Almeida-Muradian, L. B., \& Vilas-Boas, M. (2017). Phenolic composition and antioxidant activity assessment of southeastern and south Brazilian propolis. Journal of Apicultural Research, 56(1), 21-31. https://doi.org/10.1080/00218839.2016.1277602 Costamagna, M. S., Zampini, I. C., Alberto, M. R., Cuello, S., Torres, S., Pérez, J., ... Isla, M. I. (2016). Polyphenols rich fraction from Geoffroea decorticans fruits flour affects key enzymes involved in metabolic syndrome, oxidative stress and inflammatory process. Food Chemistry, 190, 392-402. https://doi.org/10.1016/j.foodchem.2015.05.068

Erdtman, G. (1960). The acetolysis method: A revised description. Svensk Botanik Tidskrift, 54, $516-564$.

García, M. E., Reyes, N. J. F., \& Rios, H. G. (2012). Atlas polínico del NOA: Compendio fotográfico de granos de polen de plantas nativas y cultivadas del noroeste argentino (pp. 131). Madrid, Spain: Académica Española.

Govindarajan, R., Rastogi, S., Vijayakumar, M., Shirwaikar, A., Rawat, A. K. S., Mehrotra, S., \& Pushpangadan, P. (2003). Studies on the antioxidant activities of Desmodium gangeticum. Biological \& Pharmaceutical Bulletin, 26(10), 1424-1427. https://doi.org/10.1248/bpb.26.1424 Guzelmeric, E., Ristivojević, P., Trifković, J., Dastan, T., Yilmaz, O., Cengiz, O., \& Yesilada, E. (2018). Authentication of Turkish propolis through HPTLC fingerprints combined with multivariate analysis and palynological data and their comparative antioxidant activity. $L W T$ Food Science \& Technology, 87, 23-32. https://doi.org/10.1016/j.lwt.2017.08.060

Herrera, T., del Hierro, J. N., Fornari, T., Reglero, G., \& Martin, D. (2019). Inhibitory effect of quinoa and fenugreek extracts on pancreatic lipase and $\alpha$-amylase under in vitro traditional conditions or intestinal simulated conditions. Food Chemistr $\gamma, 270,509-517$. https://doi.org/10.1016/j.foodchem.2018.07.145

Isla, M. I., Dantur, Y., Salas, A., Danert, C., Zampini, C., Arias, M., ... Nieva Moreno, M. I (2012). Effect of seasonality on chemical composition and antibacterial and anticandida activities of Argentine propolis. Design of a topical formulation. Natural Product Communications, 7, 1315-1318.

Isla, M. I., Moreno, A., Nuño, G., Carabajal, A., Aberto, M. R., \& Zampini, I. C. (2016). Zuccagnia punctata Cav.: A review of its traditional uses, phytochemistry, pharmacology and toxicology. NPC: Review. Natural Product Communications, 11, 1749-1755.

Isla, M. I., Paredes Guzman, J. F., Nieva Moreno, M. I., Koo, H., \& Park, Y. K. (2005). Some chemical composition and biological activity of Northern Argentine propolis. Journal of Agricultural and Food Chemistry, 53, 1166-1172. https://doi.org/10.1021/jf040130h

Isla, M. I., Zampini, C., Ordóñez, R., Cuello, S., Carrasco Juarez, B., Sayago, J., Maldonado, L. (2009). Effect of seasonal variations and collection form on antioxidant activity of propolis from San Juan, Argentina. Journal of Medicinal Food, 12, 1-9. https://doi.org/10.1089/jmf.2008.0286

Kumazawa, S., Ahn, M. R., Fujimoto, T., \& Kato, M. (2010). Radical-scavenging activity and phenolic constituents of propolis from different regions of Argentina. Natural Product Research, 24, 804-812. https://doi.org/10.1080/14786410802615270

Kurek-Górecka, A., Rzepecka-Stojko, A., Górecki, M., Stojko, J., Sosada, M., \& ŚwierczekZięba, G. (2014). Structure and antioxidant activity of polyphenols derived from propolis Molecules (Basel, Switzerland), 19(1), 78-101. https://doi.org/10.3390/molecules19010078

Lersten, N. R., \& Curtis, J. D. (1996). Survey of leaf anatomy, especially secretory structures, of tribe Caesalpinieae (Leguminosae, Caesalpinioideae). Plant Systematics and Evolution, 200, 1-39. Retrieved from https://www.jstor.org/stable/23642837

Mahapatra, D. K., Asati, V., \& Bharti, S. K. (2015). Chalcones and their therapeutic targets for the management of diabetes: Structural and pharmacological perspectives. European Journal of Medicinal Chemistry, 92, 839-865. https://doi.org/10.1016/j.ejmech.2015.01.051

Mahapatra, D. K., \& Bharti, S. K. (2016). Therapeutic potential of chalcones as cardiovascular agents. Life Sciences, 148, 154-172. https://doi.org/10.1016/j.lfs.2016.02.048

Mercado, M. I., Ruiz, A. I., Zampini, I. C., Nuño, G., Cuello, S., Isla, M. I., \& Ponessa, G. I. (2013). Arquitectura y morfoanatomía foliar y caulinar de Zuccagnia punctata (Fabaceae). Histolocalización de compuestos bioactivos. Lilloa, 50, 58-68. ISSN 2346-9641

Mercado, M. I., Moreno, M. A., Ruiz, A. I., Rodríguez, I. F., Zampini, C. I., Isla, M. I., \& Ponessa, G. I. (2018). Morphoanatomical and histochemical characterization of Larrea species from Northwestern Argentina. Revista Brasileira de Farmacognosia, 28(4), 393-401. https://doi.org/10.1016/j.bjp.2018.05.012

Morello, J., Matteucci, S., Rodriguez, A., \& Silva, M. (2012). Ecorregiones y complejos ecosistémicos argentinos (pp. 309-348). Buenos Aires, Argentina: Orientación Gráfica.

Moreno, M. A., Gómez-Mascaraque, L., Arias, M., Zampini, I. C., Sayago, J. E., Pino Ramos, L. L., ... Isla, M. I. (2018). Electrosprayed chitosan microcapsules a delivery vehicles for vaginal phytoformulations. Carbohydrate Polymers, 201, 425-437. https://doi.org/10.1016/j.carbpol.2018.08.084

Moreno, M. A., Nuño, G., Cuello, S., Zampini, I. C., Mercado, M., Ponessa, G., ... Isla, M. I. (2015). Histochemical localization and characterization of chalcones in foliar surface of Zuccagnia punctata Cav. Insight into their physiological role. Phytochemistry Letters, 13, 134-140. https://doi.org/10.1016/j.phytol.2015.05.026

Nieva Moreno, M. I., Isla, M. I., Cudmani, N. G., Vattuone, M. A., \& Sampietro, A. R. (1999) Screening of antibacterial activity of Amaicha del Valle (Tucumán, Argentina) propolis. Journa of Ethnopharmacology, 68, 97-102. https://doi.org/10.1016/S0378-8741(99)00051-3

Nieva Moreno, M. I., Isla, M. I., Vattuone, M. A., \& Sampietro, A. R. (2000). Comparison of the free radical-scavenging activity of propolis from several regions. Journal of Ethnopharmacology, 71, 109-114. https://doi.org/10.1016/s0378-8741(99)00189-0

Nieva Moreno, M. I., Zampini, I. C., Ordóñez, M., Vattuone, M. A., \& Isla, M. I. (2005). Evaluation of the cytotoxicity, mutagenicity and antimutagenicity of propolis from Amaich del Valle, Tucumán, Argentina. Journal of Agriculture and Food Chemistry, 53, 8957-8962. https://doi.org/10.1021/jf0513359

Orqueda, M. E., Zampini, I. C., Torres, S., Alberto, M. R., Ramos, L. L. P., SchmedaHirschmann, G., \& Isla, M. I. (2017). Chemical and functional characterization of skin, pulp and seed powder from the Argentine native fruit mistol (Ziziphus mistol). Effects of phenolic fractions on key enzymes involved in metabolic syndrome and oxidative stress. Journal of Functional Foods, 37, 531-540. https://doi.org/10.1016/j.jff.2017.08.020

Pistón, M., Machado, I., Branco, C. S., Cesio, V., Heinzen, H., Ribeiro, D., \& Freitas, M. (2014) Infusion, decoction and hydroalcoholic extracts of leaves from artichoke (Cynara cardunculus L. subsp. cardunculus) are effective scavengers of physiologically relevant ROS and RNS. Food Research International, 64, 150-156. https://doi.org/10.1016/j.foodres.2014.05.078

Salas, A. L., Ordóñez, R. M., Silva, C., Maldonado, L., Bedascarrasbure, E., Isla, M. I., \& Zampini, I. C. (2014). Antimicrobial activity of Argentinean propolis against Staphylococcus isolated of canine otitis. Journal of Experimental Biology and Agricultural Sciences, 2, 197-207. 
Salas, A. L., Alberto, M. R., Zampini, I. C., Cuello, A. S., Maldonado, L., Ríos, J. L., \& Isla, M. I. (2016). Biological activities of polyphenols-enriched propolis from Argentina arid regions. Phytomedicine, 23(1), 27-31. https://doi.org/10.1016/j.phymed.2015.11.007

Salas, A., Mercado, M. I., Zampini, I. C., Ponessa, G. I., \& Isla, M. I. (2016). Determination of botanical origin of propolis from Monte region of Argentina by histological and chemical methods. Natural Products Communications, 11(5), 627-630.

Salas, A., Zampini, I. C., Maldonado, L., \& Isla, M. I. (2018). Development of a bioproduct for medicinal use with extracts of Zuccagnia-type propolis. Natural Products Communications, 13(2), $167-170$.

Salatino, A., \& Salatino, M. L. F. (2017). Why do honeybees exploit so few plant species as propolis sources? MOJ Food Process Technology, 4(5), 107-109. https://doi.org/10.15406/mojfpt.2017.04.00107

Solórzano, E., Vera, N., Cuello, S., Ordóñez, R., Zampini, C., Maldonado, L., ... Isla, M. I. (2012). Chalcones in bioactive Argentine propolis collected in arid environments. Natural Products Communications, 7, 879-882.

Solórzano, E. R., Bortolini, C., Bogialli, S., Di Gangi, I. M., Favaro, G., Maldonado, L., \&

Pastore, P. (2017). Use of a LC-DAD-QTOF system for the characterization of the phenolic profile of the argentinean plant Zuccagnia punctata and of the related propolis: New biomarkers Journal of Functional Foods, 33, 425-435. https://doi.org/10.1016/j.jff.2017.04.003

Spínola, V., \& Castilho, P. C. (2017). Evaluation of Asteraceae herbal extracts in the management of diabetes and obesity. Contribution of caffeoylquinic acids on the inhibition of digestive enzymes activity and formation of advanced glycation end-products (in vitro). Phytochem, 143, 29-35. https://doi.org/10.1016/j.phytochem.2017.07.006

Valentao, P., Fernandes, E., Carvalho, F., Andrade, P. B., Seabra, R. M., \& Bastos, M. L. (2001). Antioxidant activity of Centaurium erythraea infusion evidenced by its superoxide radical scavenging and xanthine oxidase inhibitory activity. Journal of Agricultural and Food Chemistry, 49(7), 3476-3479. https://doi.org/10.1021/jf001145s

Vera, N., Solórzano, E., Ordóñez, R., Maldonado, L., Bedascarrasbure, E., \& Isla, M. I. (2011) Chemical composition of Argentinean propolis collected in extreme regions and its relation with antimicrobial and antioxidant activities. Natural Products Communications, 6, 823-827.

Wodehouse, R. P. (1935). Pollen grains (pp. 559). Mc Graw-Hill Book Company, Inc: New York and Londonf. 